\title{
An Aspergillus nidulans $\beta$-mannanase with high transglycosylation capacity revealed through comparative studies within glycosidase family 5
}

\author{
Anna Rosengren - Sumitha K. Reddy • \\ Johan Svantesson Sjöberg • Oskar Aurelius • \\ Derek T. Logan • Katarína Kolenová • Henrik Stålbrand
}

Received: 16 April 2014 /Revised: 28 May 2014 / Accepted: 29 May 2014 /Published online: 21 June 2014

(C) The Author(s) 2014. This article is published with open access at Springerlink.com

\begin{abstract}
Mannanases are involved in the conversion and modification of mannan-based saccharides. Using a retaining mechanism, they can, in addition to hydrolysis, also potentially perform transglycosylation reactions, synthesizing new glycoconjugates. Transglycosylation has been reported for $\beta$ mannanases in GH5 and GH113. However, although they share the same fold and catalytic mechanism, there may be differences in the enzymes' ability to perform transglycosylation. Three GH5 $\beta$-mannanases from Aspergillus nidulans, AnMan5A, AnMan5B and AnMan5C, which belong to subfamily GH5 7 were studied. Comparative studies, including the GH5_7 TrMan5A from Trichoderma reesei, showed some differences between the enzymes. All the enzymes could perform transglycosylation but AnMan5B stood out in generating comparably higher amounts of transglycosylation products when incubated with manno-oligosaccharides. In addition, AnMan5B did not use alcohols as acceptor, which was also different compared to the other three $\beta$-mannanases. In order to map the preferred binding of manno-oligosaccharides, incubations were performed in $\mathrm{H}_{2}{ }^{18} \mathrm{O}$. AnMan5B in contrary to the other enzymes did not generate any ${ }^{18} \mathrm{O}$-labelled products. This further supported the idea that AnMan5B potentially prefers to use saccharides as acceptor instead of water. A homology
\end{abstract}

Electronic supplementary material The online version of this article (doi:10.1007/s00253-014-5871-8) contains supplementary material, which is available to authorized users.

A. Rosengren $\cdot$ S. K. Reddy $\cdot$ J. S. Sjöberg $\cdot$ O. Aurelius $\cdot$

D. T. Logan $\cdot K$. Kolenová $\cdot H$. Stålbrand $(\bowtie)$

Department of Biochemistry and Structural Biology, Lund

University, P.O. Box 124, 22100 Lund, Sweden

e-mail: Henrik.Stalbrand@biochemistry.lu.se

Present Address:

K. Kolenová

Institute of Chemistry, Center for Glycomics, Slovak Academy of

Sciences, Dúbravská cesta 9, 84538 Bratislava, Slovakia model of AnMan5B showed a non-conserved Trp located in subsite +2 , not present in the other studied enzymes. Strong aglycone binding seems to be important for transglycosylation with saccharides. Depending on the application, it is important to select the right enzyme.

Keywords $\beta$-mannanase - GH5 - Transglycosylation . $\mathrm{H}_{2}{ }^{18} \mathrm{O} \cdot$ Acceptor $\cdot$ MALDI-TOF MS

\section{Introduction}

$\beta$-Mannosidic linkages are abundant in nature, notably present in hemicellulose such as spruce galactoglucomannan and in plant storage galactomannans (Scheller and Ulvskov 2010). These $\beta$-mannan polysaccharides are important renewable resources and their enzymatic conversion is of great interest in sustainable biorefinery processes (Carvalheiro et al. 2008). $\beta$-Mannanases are the main endo-acting enzymes that hydrolyze $\beta$-1,4-linkages in $\beta$-mannans (Gilbert et al. 2008). So far, $\beta$-mannanases have been classified into glycoside hydrolase (GH) families 5, 26 and 113, as displayed in the CAZy database; www.cazy.org, (Cantarel et al. 2009; Lombard et al. 2014). GH5 is a diverse family, encompassing not only $\beta$-mannanases but also a range of other enzymatic activities from a variety of organisms. GH5 enzymes are $(\beta / \alpha)_{8}$ TIMbarrels and several $\beta$-mannanase 3D structures from the family have been published, six of which are from eukaryotic organisms (Bourgault et al. 2005; Couturier et al. 2013; Goncalves et al. 2012; Larsson et al. 2006; Mizutani et al. 2012; Sabini et al. 2000). Although having the same basic catalytic specificity (i.e. hydrolysis of $\beta$-mannosidic bonds), there may be differences in the biological functions of $\beta$ mannanases; e.g. microbial $\beta$-mannanases of saphrophytic fungi take part in the degradation of woody plant tissues 
(Coutinho et al. 2009) while some plant $\beta$-mannanases are involved in germination (Iglesias-Fernandez et al. 2011). Functional differences are also present among bacterial $\beta$ mannanases (Tailford et al. 2009). Choosing the right enzyme for a certain biotechnological application, such as for biomass saccharification or for enzymatic synthesis, is crucial. Therefore, comparative biochemical studies of $\beta$ mannanases are of great importance to expand knowledge on functional diversity and on structural features that influence specific functions. This will also contribute to an increased understanding of the biological role of $\beta$-mannanases. Recently, enzymes in GH5 were classified into subfamilies based on sequence similarities and phylogenetic analysis, which grouped $\beta$-mannanases into subfamilies 7, 8, 10 and 17 (GH5 7, GH5 8, GH5 10 and GH5 17) (Aspeborg et al. 2012). Although enzymes with high sequence identity are likely to share similar functions, there might still be differences within subfamilies. However, this has not yet been well studied. $\beta$-Mannanases use the retaining double displacement mechanism and can in principle carry out transglycosylation, i.e. enzymatic synthesis of $\beta$-mannosidic bonds - arguably the most difficult glycosidic bond to synthesize chemically (Gridley and Osborn 2000). Enzymatic synthesis of glycoconjugates such as alkyl-glycosides can in general be carried out with transglycosylating glycoside hydrolases which use the retaining catalytic mechanism (van Rantwijk et al. 1999). The first step of this mechanism is a nucleophilic attack on the anomeric carbon. The aglycone part of the sugar is released and a covalent intermediate is formed between the enzyme and the glycone. In the second step, the glycone serves as donor to either a water molecule (in hydrolysis) or to another acceptor such as a sugar (in transglycosylation).

Transglycosylation has so far been reported for GH5 $\beta$ mannanases in GH5 7 and GH5 10 (Couturier et al. 2013; Dilokpimol et al. 2011; Harjunpaa et al. 1999; Larsson et al. 2006; Schroder et al. 2006) as well as for one bacterial GH113 $\beta$-mannanase (Zhang et al. 2008). In the tomato plant, it has been suggested that a GH5_7 enzyme may take part in plant cell wall remodelling, due to displaying mannosyl transglycosylation/transferase activity in addition to $\beta$ mannanase activity (Schroder et al. 2006). At present, there are no reports on any native GH26 $\beta$-mannanase with the ability to perform transglycosylation. The molecular characteristics connected to transglycosylation capacity of $\beta$ mannanases are not completely revealed although some recent advances have been achieved (Hekmat et al. 2010; Dilokpimol et al. 2011; Rosengren et al. 2012). Interactions between the enzyme and its substrate take place at different subsites in the active site, where negative numbers represent glycone-binding subsites and positive numbers represent aglycone binding subsites (Davies et al. 1997). Strong aglycone binding has been suggested to be important for $\beta$-mannanases to be able to transglycosylate (Larsson et al. 2006; Rosengren et al. 2012).
A previous study of the $\beta$-mannanase from Trichoderma reesei, TrMan5A, showed that engineering of the +2 subsite, mutating an Arg to a Lys, changed the substrate binding and significantly reduced transglycosylation onto sugars. Interestingly, although transglycosylation capacity with sugar acceptors was reduced, the ability to transfer to alcohol acceptors was retained (Rosengren et al. 2012). Besides T. reesei, other fungi such as for example Aspergillus sp. (Coutinho et al. 2009; Bien-Cuong et al. 2009) are biotechnologically interesting sources of $\beta$ mannanases and other carbohydrate converting enzymes. Three Aspergillus nidulans GH5 endo- $\beta$-1,4-mannanase genes (manA, $\operatorname{man} B$ and $\operatorname{man} C$ ) were previously cloned into Pichia pastoris and the culture filtrate of induced cells showed hydrolytic activity on galactomannan (Bauer et al. 2006). The three A. nidulans $\beta$-mannanase sequences are all predicted to have a signal peptide for secretion. The gene products AnMan5A, AnMan5B and AnMan5C belong to GH5_7. However, they cluster in different groups in the phylogenetic tree of GH5_7 (Aspeborg et al. 2012). Biochemical characterisation of AnMan5A and AnMan5C has shown that they are both able to perform transglycosylation (Dilokpimol et al. 2011). The aim of this study was to characterise AnMan5B and by comparative studies with the paralogous AnMan5A and AnMan5C as well as with TrMan5A, which is the closest homolog with a solved 3D structure, further expand the knowledge about differences in transglycosylation, substrate binding and alcohol transfer by $\beta$ mannanases in GH5. This is interesting from a fundamental point of view and is also of great importance to improve the selection procedure of enzymes as tools for different biotechnological applications. Our findings reveal that although belonging to the same GH family and subfamily, the three paralogous $A$. nidulans $\beta$-mannanases and the homologous TrMan5A show significant differences in function, in respect to transglycosylation and acceptor usage.

\section{Materials and methods}

\section{Sequence analysis}

The amino acid sequence of $A$. nidulans AnMan5B (AN3297.2, UniProt entry Q5B833) was analysed for presence of signal peptide (SignalP server, http://www.cbs.dtu.dk/ services/SignalP/), glycosylation sites (NetNGlyc 1.0 server, http://www.cbs.dtu.dk/services/NetNGlyc/), molecular weight and pI (Expasy ProtParam tool, http://web.expasy. org/protparam/). Multiple sequence alignments of GH5 $\beta$ mannanases were performed using Clustal Omega (http:// www.ebi.ac.uk/Tools/msa/clustalo/), including characterised Aspergillus GH5 $\beta$-mannanases, structure determined GH5 $\beta$-mannanases and characterised fungal GH5 $\beta$-mannanases with more than $50 \%$ sequence identity to AnMan5B. For accession entries, see Table 1. 
Table 1 Amino acid sequences used in the multiple sequence alignment analysis of GH5 $\beta$ mannanases. Listed are: the sequence name displayed in the alignment, subfamily, organism and accession entries for UniProt (bold), PDB (underlined) or GeneBank (italics). Additional accession entries are shown in parenthesis

\begin{tabular}{|c|c|c|c|}
\hline Name in alignment & Subfamily & Organism & Accession entry \\
\hline AnMan5B & 7 & Aspergillus nidulans & Q5B833 \\
\hline TrMan5A_1QNR & 7 & Trichoderma reesei & $\underline{\text { 1QNR }}(\mathbf{Q 9 9 0 3 6})$ \\
\hline Phialophora & 7 & Phialophora sp. & DSIF02 \\
\hline Bispora & 7 & Bispora sp. & B5LXD7 \\
\hline A.niger_BK-01 & 7 & Aspergillus niger & B6V878 \\
\hline A. aculeatus & 7 & Aspergillus aculeatus & Q00012 \\
\hline A. fumigatus & 7 & Aspergillus fumigatus & Q4WBS1 \\
\hline A. niger_CBS513.88 & 7 & Aspergillus niger & A2QKT4 \\
\hline A. sulphureus & 7 & Aspergillus sulphureus & Q2LE69 \\
\hline PaMan5A_3ZIZ & 7 & Podospora anserina & $\underline{\text { 3ZIZ }}(\mathbf{B} 2 \mathrm{~B} 3 \mathrm{CO})$ \\
\hline AnMan5A & 7 & Aspergillus nidulans & Q5B7X2 \\
\hline AnMan5C & 7 & Aspergillus nidulans & Q5A253 \\
\hline CsMan_4AWE & 7 & Crysonila sitophila & 4AWE (CCI55471.1) \\
\hline TpMan_3PZQ & 7 & Thermotoga petrophila & 3PZQ (A5IMX7) \\
\hline LeMan_1RH9 & 7 & Solanum lycopersicum & $\underline{\text { 1RH9 }}$ (Q8L5J1) \\
\hline C.mixtus_1UUQ & 7 & Celvibrio mixtus & $\underline{1 \mathrm{UUQ}}$ (Q6QT42) \\
\hline MeMan5A_2COH & 10 & Mytilus edulis & $\underline{2 \mathrm{COH}}$ (Q8WPJ2) \\
\hline AkMan_3VUP & 10 & Aplysia kurodai & 3VUP $(B A J 60954.1)$ \\
\hline TfMan_1BQC & 8 & Thermobifida fusca KW3 & $\underline{\text { 1BQC }}$ (Q9ZF13) \\
\hline BaMan_3WHJ & 8 & Bacillus agaradharens & $\underline{3 \mathrm{WHJ}}(A A N 27517.1)$ \\
\hline B. sp N16-5_3JUG & 8 & Bacillus sp. N16-5 & 3JUG (Q5YEX6) \\
\hline B. sp JAMB620_1WKY & 8 & Bacillus sp. JAMB-602 & $\underline{1 \mathrm{WKY}}(\mathbf{Q} 4 \mathbf{W 8 M 3})$ \\
\hline
\end{tabular}

Expression and purification of enzymes

$P$. pastoris $\mathrm{X}-33$ strains harbouring genes encoding the fulllength A. nidulans $\beta$-mannanases AnMan5A, AnMan5B or AnMan5C were obtained from Fungal Genetics Stock Center (FGSC, School of Biological Sciences, University of Missouri, Kansas City, MO) with accession no. 10088 (AN3358.2) for AnMan5A, no. 10086 (AN3297.2) for AnMan5B and no. 10106 (AN6427.2) for AnMan5C. The genes were previously cloned from cDNA of $A$. nidulans by others (Bauer et al. 2006). Enzymes were expressed and purified as in (Bauer et al. 2005) and following the recommendations in the Easy select Pichia expression kit manual (Invitrogen, Lidingö, Sweden). Cells were grown in $50 \mathrm{~mL}$ of buffered complex medium in a $250-\mathrm{mL}$ flask in an orbital shaker $(250 \mathrm{rpm})$ at $28{ }^{\circ} \mathrm{C}$ to an $\mathrm{OD}_{600}$ of 3-6. Aliquots of cells were then diluted to an $\mathrm{OD}_{600}$ of 1.0 with $200 \mathrm{~mL}$ of buffered complex medium containing methanol and incubated for 3-5 days with daily addition of methanol up to $0.5 \%$. The cultures were harvested by centrifugation $(10 \mathrm{~min}, 5,000 \times \mathrm{g})$ and the supernatant was concentrated using an Amicon Ultra15 centrifugal unit with $10 \mathrm{kDa}$ cut-off (Millipore, Solna, Sweden). A 1-ml Ni-NTA Superflow cartridge (Qiagen, Germantown, USA) was used for purification of the Histagged proteins according to the manufacturer's recommendations. Protein purity was analysed with electrophoresis using NuPAGE Novex Bis-Tris gels 4-12\% (Invitrogen, Lidingö, Sweden) or $12 \%$ polyacrylamide gels casted in lab. PageRuler ${ }^{\mathrm{TM}}$ Unstained Protein Ladder (Fermentas, Gothenburg, Sweden) was included for molecular weight estimation. Gels were stained with quick colloidal CBB-staining in water using microwave heating, as described in (Lawrence and Besir 2009). Purified enzymes were treated with endoglycosidase $\mathrm{H}$ (endoH) (New England BioLabs, Ipswich, MA) according to the manufacturer's recommendations, in order to analyse N-glycosylation. Protein concentrations were determined using Pierce BCA Protein Assay (Thermo Fisher scientific, Rockford, USA) or NanoDrop ${ }^{\circledR}$ (ND-1000 spectrophotometer, Saveen Werner, Sweden) measuring absorbance at $280 \mathrm{~nm}$ and using extinction coefficients $\mathrm{M}^{-1} \mathrm{~cm}^{-1}[\varepsilon]=90675$ for AnMan5A, $[\varepsilon]=118510$ for AnMan5B and $[\varepsilon]=115405$ for AnMan5C, calculated from the amino acid sequences using the ExPASy tool ProtParam (http://web.expasy.org/protparam/). The identity of the proteins was confirmed with mass spectrometry and N-terminal sequencing of AnMan5B was done using a service provided by Proteome Factory (Proteome Factory AG, Berlin, Germany). The Trichoderma reesei $\beta$-mannanase TrMan5A was produced as in (Rosengren et al. 2012). 
Mannanase activity assay and enzyme characterisation

$\beta$-Mannanase activity was assayed with $0.5 \%$ locust bean galactomannan (LBG) (Sigma St. Louis, MO) in $50 \mathrm{mM} \mathrm{Na-}$ citrate buffer using the 3,5-dinitrosalicylic acid (DNS) method as described previously (Stalbrand et al. 1993). Appropriately diluted enzyme $(40 \mu \mathrm{l})$ was mixed with substrate $(360 \mu \mathrm{l})$ and incubated for $10 \mathrm{~min}$ at $37^{\circ} \mathrm{C}$. The reaction was stopped by addition of DNS $(600 \mu \mathrm{l})$, followed by $10 \mathrm{~min}$ boiling. After cooling the samples absorbance was measured at $540 \mathrm{~nm}$ and correlated to the amount of reducing ends based on a mannose standard curve. The $\mathrm{pH}$-optimum was determined using $0.5 \%$ LBG in $50 \mathrm{mM}$ buffers of different $\mathrm{pH}$ (citrate $\mathrm{pH} 3-6$, phosphate $\mathrm{pH}$ 6.5-8, citrate-phosphate $\mathrm{pH}$ 5.5-7 and Tris$\mathrm{HCl} \mathrm{pH} \mathrm{7.5-9).} \mathrm{The} \mathrm{temperature} \mathrm{optimum} \mathrm{was} \mathrm{determined} \mathrm{by}$ assaying the activity at optimal $\mathrm{pH}$ in temperatures from 35 to $70{ }^{\circ} \mathrm{C}$ as described above. The stability at $37^{\circ} \mathrm{C}$ was tested by assaying the residual activity after incubating the enzymes for up to $24 \mathrm{~h}$ at $\mathrm{pH} 6$.

Kinetics with locust bean galactomannan

The kinetic constants for the LBG hydrolysis were determined by assaying the initial $\beta$-mannanase activity at different substrate concentrations ( 5 to $0.313 \mathrm{mg} / \mathrm{mL}$ ) using the DNS assay as described above. The enzyme concentrations used were 145 nM AnMan5A, 1804 nM AnMan5B and 114 nM AnMan5C. The initial hydrolysis rate was plotted as a function of the substrate concentration by non-linear regression in a Michaelis-Menten graph to obtain the values for $k_{\text {cat }}, K_{\mathrm{M}}$ and $k_{\text {cat }} / K_{\mathrm{M}}$.

Incubations with mannans and manno-oligosaccharides

Ivory nut mannan (5 mg/mL) (Megazyme, Bray, Ireland), mannobiose $\left(\mathrm{M}_{2}\right)$ mannotriose $\left(\mathrm{M}_{3}\right)$, mannotetraose $\left(\mathrm{M}_{4}\right)$, mannopentaose $\left(\mathrm{M}_{5}\right)$ and mannohexaose $\left(\mathrm{M}_{6}\right)$ (Megazyme, Bray, Ireland) (5 mM) and manno-oligosaccharides with galactose substitutions; $6^{1}$ - $\alpha$-D-galactosyl-mannobiose $\left(\mathrm{GM}_{2}\right)$, $6^{1}$ - $\alpha$-D-galactosyl-mannotriose $\left(\mathrm{GM}_{3}\right), 6^{3}-6^{4}-\alpha$-D-galactosylmannopenatose $\left(\mathrm{G}_{2} \mathrm{M}_{5}\right)$ (Megazyme, Bray, Ireland) $(5 \mathrm{mM})$ were incubated overnight at $37^{\circ} \mathrm{C}$ with AnMan5A (73 nM), AnMan5B (902 nM) and AnMan5C (57 nM). Na-citrate buffer $50 \mathrm{mM}$ pH 5.5 was used with AnMan5A and AnMan5C and Na-citrate buffer $50 \mathrm{mM}$ pH 6 was used with AnMan5B. The reactions were stopped by boiling and samples were analysed with thin-layer chromatography (TLC). Samples $(2 \mu \mathrm{l})$ were applied onto a silica plate (Merck, Darmstadt, Germany) and the chromatography was run in a system of butanol/ethanol/ water $(10: 8: 7, v / v)$ for $8 \mathrm{~h}$. The sugars were visualized using an $N$-(1-naphtyl) ethylenediamine dihydrochloride solution containing ethanol and sulfuric acid (Bounias 1980). The solution was poured on the TLC plate which was then dried and developed at $105{ }^{\circ} \mathrm{C}$ for 5-15 min. Manno-oligosaccharides $\mathrm{M}_{1}-\mathrm{M}_{6}(10 \mathrm{mM})$ were included as standards.

Time course incubations with $\mathrm{M}_{4}$

A time course study of reactions with $\mathrm{M}_{4}$ was done by incubating $5 \mathrm{mM} \mathrm{M}_{4}$ with two different enzyme loads, based on LBG kinetics (0.05 and 1 nkat), of AnMan5A (15 and $290 \mathrm{nM}$ ), AnMan5B (450 and 9,045 nM) and AnMan5C (15 and $300 \mathrm{nM}$ ) for $0-24 \mathrm{~h}$ at $37^{\circ} \mathrm{C}$ in $50 \mathrm{mM} \mathrm{Na}$-citrate buffer pH 5.5 (AnMan5A and AnMan5C) or pH 6 (AnMan5B). Aliquots were withdrawn at different time points, the reactions were stopped by boiling and the samples were analysed with TLC as described above.

Transglycosylation reactions with $\mathrm{M}_{4}$

Reactions with $30 \mathrm{mM} \mathrm{M}_{4}$ were set up with AnMan5B and TrMan5A (330 nM). Na-citrate buffer $50 \mathrm{mM} \mathrm{pH} 6$ was used with AnMan5B and Na-acetate buffer $50 \mathrm{mM}$ pH 4.5 was used with TrMan5A. Incubations were done at $37^{\circ} \mathrm{C}$ for 0 $180 \mathrm{~min}$, aliquots were withdrawn at regular time intervals and the reactions were stopped by $5 \mathrm{~min}$ boiling. Analysis was done with high performance anion exchange chromatography with pulsed amperometric detection (HPAEC-PAD) and matrix-assisted laser desorption/ionisation time-of-flight mass spectrometry (MALDI-TOF MS). For HPAEC-PAD analysis a Dionex CX 500 system (Dionex, Sunnyvale CA, USA) including an AS50 auto sampler, a GP40 gradient pump and an ED40 electrochemical detector was used. Samples were run on CarboPac PA-100 analytical and guard columns and elution was performed with $100 \mathrm{mM} \mathrm{NaOH}$ at a flow rate of $1 \mathrm{ml} / \mathrm{min}$. The injection volume was $10 \mu \mathrm{l}$ and manno-oligosaccharides $\mathrm{M}_{1}-\mathrm{M}_{6}$ were used as standards. $\mathrm{M}_{7}$ products were quantified using the standard for $\mathrm{M}_{6}$. For MALDI-TOF MS analysis, samples $(0.5 \mu \mathrm{l})$ were spotted directly onto a MALDI plate, supplied with matrix $(10 \mathrm{mg} / \mathrm{ml}$ 2,5-dihydroxybenzoic acid (DHB) in water) and dried under warm air.

Kinetics with manno-oligosacharides

The kinetic parameter $k_{\text {cat }} / K_{\mathrm{M}}$ was determined with AnMan5B (2.5-100 nM) for $\mathrm{M}_{3}-\mathrm{M}_{6}$, by following the substrate conversion over time (0-180 $\mathrm{min}$ for $\mathrm{M}_{3}$ and 0-60 min for $\left.\mathrm{M}_{4}-\mathrm{M}_{6}\right)$ at low $(\leq 50 \mu \mathrm{M})$ substrate concentration in $50 \mathrm{mM}$ Na-citrate pH 6 at $37^{\circ} \mathrm{C}$. Duplicate samples were analysed with HPAECPAD using a CarboPac PA-100 column as described above. $\operatorname{Ln}\left(S_{\mathrm{o}} / S_{\mathrm{t}}\right)$ was plotted as a function of time $(t)$ and $k_{\text {cat }} / K_{\mathrm{M}}$ was calculated according to the Matsui equation; $\mathrm{k}=\mathrm{Ln}\left(\mathrm{S}_{\mathrm{o}} / \mathrm{S}_{\mathrm{t}}\right)$, where $k=\left(\left(k_{\text {cat }} / K_{\mathrm{M}}\right) \times\right.$ [enzyme $\left.]\right) \times t, \mathrm{~S}_{\mathrm{o}}=$ substrate concentration at time zero and $S_{t}=$ substrate concentration at time $t$ (Matsui et al. 1991). Data was analysed using GraphPadPrism software (Graph Pad Software Inc., San Diego, CA). 
Reactions with manno-oligosaccharides in $\mathrm{H}_{2}{ }^{18} \mathrm{O}$

The relative preferred binding of manno-oligosaccharides was studied by incubations in $\mathrm{H}_{2}{ }^{18} \mathrm{O}$ followed by MALDI-TOF MS analysis, as previously described in (Hekmat et al. 2010; Rosengren et al. 2012). This approach is a development from experiments in a study of an endoglucanase where electrospray MS was used to analyse labelled cellooligosaccharides (Schagerlof et al. 2009). In the present study, AnMan5A, AnMan5B and AnMan5C (31-34 nM) were incubated with $0.8 \mathrm{mM} \mathrm{M}_{4}$ or $\mathrm{M}_{5}$ in $93 \% \mathrm{H}_{2}{ }^{18} \mathrm{O}$ (Sigma Aldrich, Schnelldorf, Germany), $1 \mathrm{mM}$ Na-citrate $\mathrm{pH} 5.5$ (AnMan5A and AnMan5C) or pH 6 (AnMan5B) for 0-24 h at $8{ }^{\circ} \mathrm{C}$. Incubations with ten times higher enzyme load (330 $\mathrm{nM}$ ) of AnMan5B were also performed in the same way with $0.8 \mathrm{mM} \mathrm{M}_{4}, \mathrm{M}_{5}$ and $\mathrm{M}_{6}$. Samples $(0.5 \mu \mathrm{l})$ were spotted directly onto a MALDI plate, supplied with matrix (10 mg/ml DHB in water) and dried under warm air.

Product formation from $\mathrm{M}_{4}$ incubations in water-alcohol mixtures

For alcohol transfer reactions, $5 \mathrm{mM} \mathrm{M}_{4}$ were mixed with either $25 \%(5.9 \mathrm{M})$ methanol or $25 \%(2.6 \mathrm{M})$ butanol and incubated in $20 \mathrm{mM}$ Na-citrate buffer $\mathrm{pH} 6$ with AnMan5A, AnMan5B and AnMan5C (210-240 nM) for 0-24 h at $37^{\circ} \mathrm{C}$. The samples were boiled and diluted ten times in $\mathrm{H}_{2} \mathrm{O}$ before spotting them on a MALDI plate and applying matrix as described above.

Transfer to $\mathrm{G}_{2} \mathrm{M}_{5}$ and ${ }^{18} \mathrm{O}$-labelled $\mathrm{G}_{2} \mathrm{M}_{5}$

To investigate the transfer capacity to $\mathrm{G}_{2} \mathrm{M}_{5}$, AnMan5B (240 nM) was incubated with $5 \mathrm{mM} \mathrm{M}_{4}$ and $5 \mathrm{mM} \mathrm{G}_{2} \mathrm{M}_{5}$ in $10 \mathrm{mM}$ Na-citrate buffer $\mathrm{pH} 6$ at $37^{\circ} \mathrm{C}$ for $4 \mathrm{~h}$. Reactions were also set up where $\mathrm{G}_{2} \mathrm{M}_{5}$ had been pre-labelled with ${ }^{18} \mathrm{O}$. The labelling was done by preparing $40 \mathrm{mM} \mathrm{G}_{2} \mathrm{M}_{5}$ in $97 \% \mathrm{H}_{2}{ }^{18} \mathrm{O}$ (Sigma Aldrich, Schnelldorf, Germany) and incubating at $90{ }^{\circ} \mathrm{C}$ for $30 \mathrm{~min}$, which resulted in $\sim 90 \%{ }^{18} \mathrm{O}$-labelling as deduced from the areas and intensities of the ${ }^{16} \mathrm{O}$ - and ${ }^{18} \mathrm{O}$-labelled peaks in the MALDI-TOF MS analysis. AnMan5B (330 nM) was incubated with $0.8 \mathrm{mM} \mathrm{M}_{4}$ and $0.8 \mathrm{mM}^{18} \mathrm{O}-\mathrm{G}_{2} \mathrm{M}_{5}$ in $1 \mathrm{mM}$ Na-citrate buffer at $8{ }^{\circ} \mathrm{C}$ up to $2 \mathrm{~h}$. The mixture contained $2 \%$ $\mathrm{H}_{2}{ }^{18} \mathrm{O}$ that came from the ${ }^{18} \mathrm{O}-\mathrm{G}_{2} \mathrm{M}_{5}$ and therefore the incubations were done at $8{ }^{\circ} \mathrm{C}$ in order to avoid non-enzymatic incorporation of ${ }^{18} \mathrm{O}$. Samples $(0.5 \mu \mathrm{l})$ were applied to the MALDI plate as described above.

\section{MALDI-TOF MS data acquisition and analysis}

Acquisition and analysis of mass spectrometry data was done essentially as described in (Hekmat et al. 2010; Rosengren et al. 2012), using a MALDI-TOF 4700 Proteomics Analyzer
(Applied Biosystems, Framingham, CA) in positive reflector mode for data acquisition. At a laser intensity of 5000, $50 \mathrm{sub}$ spectra with 20 shots on each were accumulated from a sample spot to generate a spectrum. For data analysis, the Data Explorer version 4.5 software was used.

\section{Homology modelling}

Based on the multiple sequence alignment, homology modelling of AnMan5B was performed with Prime (SchrödingerLLC 2012), using the structure of the Trichoderma reesei $\beta$ mannanase TrMan5A as template (PDB entry 1QNR). N-/Cterminal end overhangs in the target sequence relative to the aligned template, were removed. Manual adjustments of model rotamers were made in Coot (Emsley and Cowtan 2004) to increase similarity to template. Model quality was evaluated with MolProbity (Chen et al. 2010), showing that $92.8 \%$ of the amino acids were in favored Ramachandran regions and the model clashscore was 27.44 (Supplemental Table S1). Figures were prepared in PyMOL (Schrödinger-LLC 2013).

\section{Results}

Sequence analysis

A multiple amino acid sequence alignment including AnMan5A, AnMan5B, AnMan5C, TrMan5A and characterised GH5 $\beta$-mannanases revealed at least seven amino acids that are highly conserved in GH5 (Hilge et al. 1998; Lo Leggio and Larsen 2002; Sabini et al. 2000; Sakon et al. 1996; Wang et al. 1993). For AnMan5B, these are R84, N203, E204, H277, Y279, E312 and W342, with E204 and E312 predicted to be the catalytic acid base and nucleophile respectively (Fig. 1). The arginine equivalent to R171 in the +2 subsite of TrMan5A (Sabini et al. 2000), that was previously shown to play role in the transglycosylation capacity of the enzyme (Rosengren et al. 2012), is also present in the $A$. nidulans enzymes as well as in the other subfamily $7 \beta$ mannanases included in the sequence alignment.

Expression, purification and basic characterisation

Active AnMan5A, AnMan5B and AnMan5C were expressed in $P$. pastoris and purified from the culture supernatant using metal ion chromatography, and the protein identities were confirmed by mass spectrometry. N-terminal sequencing of AnMan5B showed that the amino acid sequence started with APIGN, confirming signal peptide processing. AnMan5A and AnMan5C were previously shown to carry glycosylations (Dilokpimol et al. 2011). This was also the case with AnMan5B; the molecular weight decreased from 53 to 


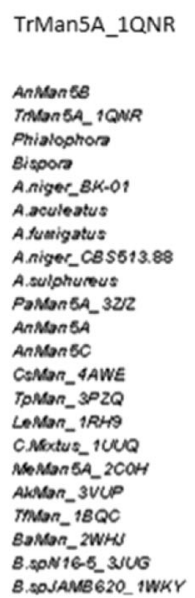
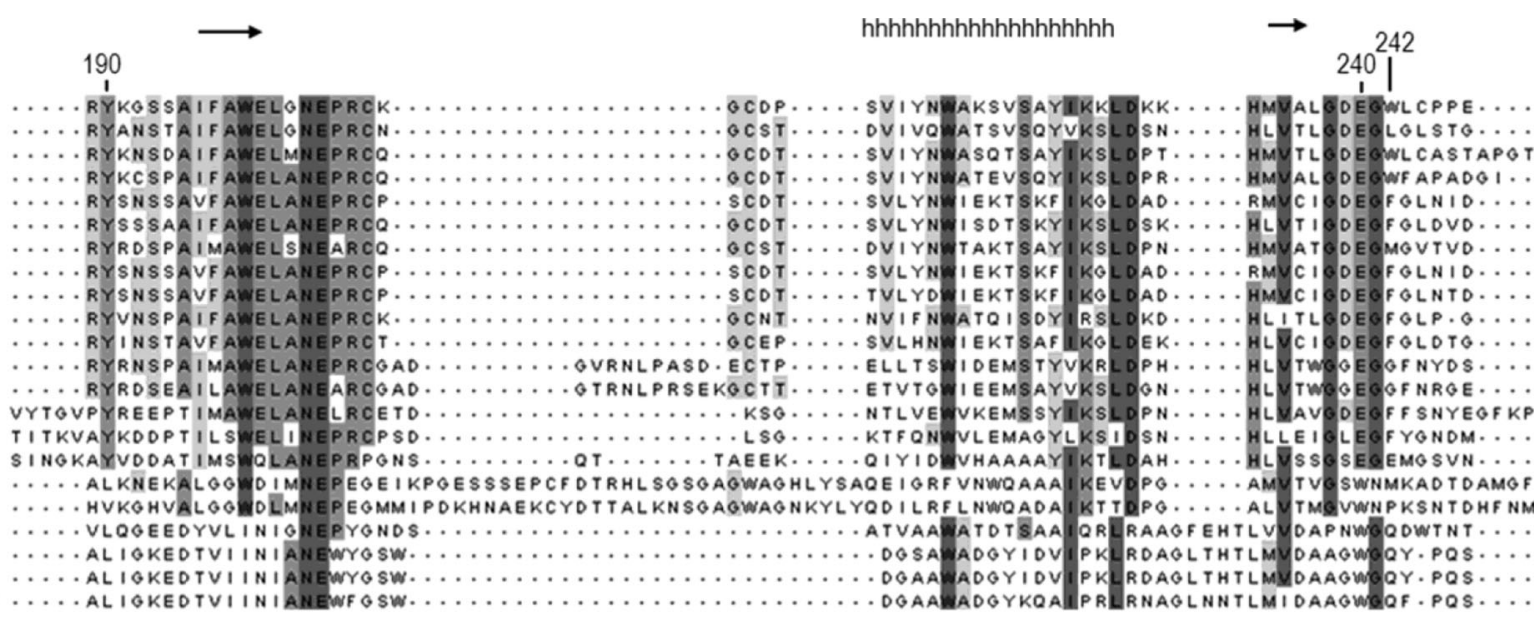

TrMan5A_1QNR hhh hhhhh $\longrightarrow$ hhhh 250

AnManse

THMON5A_1QNR

Phislophora

Sispora

A.niger_BK-O1

A. aculeatus

A.Aunitigatus

A.niger_CBS513.88

A.sulphureus

AnMan 54

AnMOABC

CoMan_4AWE

TPMOn_ $3 P 2 Q$

crastus 1 CuD

MEMONSA_2COH

ALMON_3VLP

TMOan_18QC

B.sON16-5_3UG

- DOTYAYOCSEOVDFUKNLLEIETLDYOTF DOAYPYTYOEOTDFAKNVQI KSLDEOTF VOYYLODDGSYAYSCSEOVDF SLNMO I KTLDYOTF, ..... ODOSYAYSODQQVDF VKNLO I KTLDYOTF HLYPSS ODOSYAYSODQQVDF VKNLO I KTLDYOTF HLYPSSWO. ..... SDGSYPYTYGEOLNF TKNLOISTIDFOIL HL YPOSWO ..... SDOSYPYSTYEOSDFAKNLAAPD I DF OVF HL YTEDWO $\cdots \cdots$ SDQSYPYQF SEQLNF TMNLO IDT I DFOTLHLYPDSWO *... SDQSYPYQFAEQLNF TMNLO I DTIDFATL QT TYPYOYOEOTDFUKNLQI KNLDF OTF HMYPOHWO $\ldots \ldots$ SDQ SYPFQYTEOSDFAAALTIDT I DFOTF HL
$\ldots \ldots$. DOWAYNGSDQODFEAELKLKNI DFOVFHS . DOWAYNGSDQODFEAELKLKN I DF OVF
DEEDOF YNOADQODEDRELOLRNVDFOTM ... YOOEAEWAYNOWSOVDWKKLLSIETVDFOTF ....... RQYNPNSYIFQTNF I SNNQVQG I DETT I

HNLY.......... . . HCLVKAQOKQSOTLSFYYVHT NNHY. . . . . SO... HCLRLAGGKQKGVFDFYOFH N.............

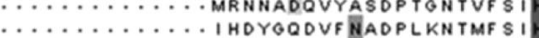
........ I HOYGQDVFNADPLKNTI I S I HMYEYAC

Fig. 1 Multiple alignment of GH5 $\beta$-mannanases including (i) characterised Aspergillus $\beta$-mannanases (ii) structure determined GH5 $\beta$-mannanases (iii) characterised fungal $\beta$-mannanases with $>50 \%$ sequence identity to AnMan5B. The figure shows the region covering the two conserved catalytic residues E204 and E312, with numbering

$43 \mathrm{kDa}$ after EndoH treatment (Supplemental Fig. S1a). AnMan5B has a pH-optimum of 6 (Supplemental Fig. S1b), comparable to AnMan5A and AnMan5C (Dilokpimol et al. 2011) and slightly higher than TrMan5A (Stalbrand et al. 1993). The temperature optimum of AnMan5B is $60^{\circ} \mathrm{C}$, also comparable to AnMan5A, AnMan5C $\left(50{ }^{\circ} \mathrm{C}\right.$ ) (Dilokpimol et al. 2011) and TrMan5A (70 $\left.{ }^{\circ} \mathrm{C}\right)$ (Stalbrand et al. 1993), and the enzyme remained stable when incubated $24 \mathrm{~h}$ at $37^{\circ} \mathrm{C}$ and $\mathrm{pH} 6$.

\section{Kinetics with LBG}

Activity on galactomannans was previously reported for AnMan5A and AnMan5C, revealing a higher specific activity for AnMan5C (Dilokpimol et al. 2011). The Michaelis-Menten kinetic parameters with LBG determined for AnMan5A, AnMan5B and AnMan5C (Table 2) showed that AnMan5B has a lower $k_{\text {cat }} / K_{\mathrm{M}}$ hhhhhhhhhhhhhhhhhhhhhhh $\longrightarrow$

310

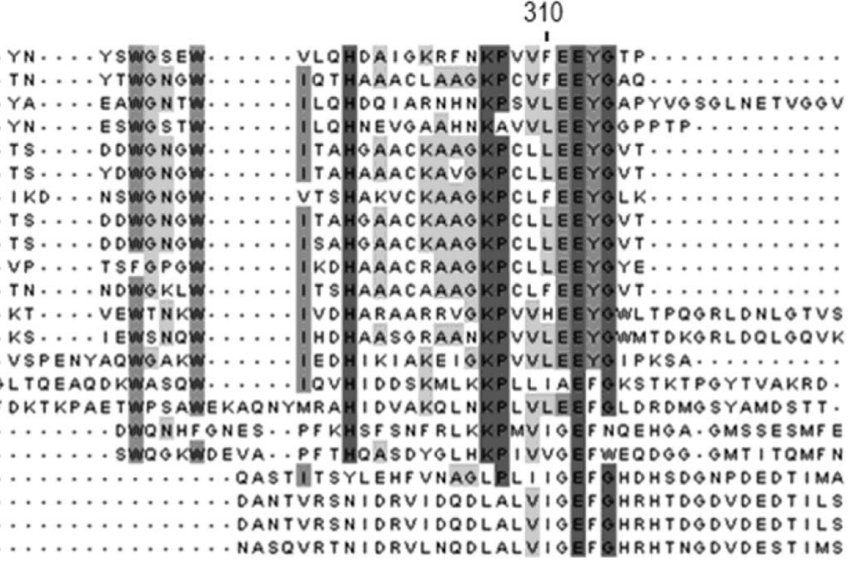

according to the AnMan5B sequence and with boxing in grey according to \% sequence identity. The non-conserved Trp242 in AnMan5B is highlighted. The secondary structure of TrMan5A (from the PDB entry 1QNR) is shown as arrows for $\beta$-strands and $h$ for helices. For accession entries, see Table 1

compared to AnMan5A and AnMan5C, and also compared to what was previously reported for TrMan5A (Rosengren et al. 2012). The low efficiency is mostly due to a low $k_{\text {cat }}$, while $K_{\mathrm{M}}$ is comparable to AnMan5A and AnMan5C but higher compared to TrMan5A (Table 2).

Table 2 Kinetic parameters on LBG of AnMan5A, AnMan5B and AnMan5C and comparison to data reported for TrMan5A

\begin{tabular}{lclc}
\hline Enzyme & $k_{\text {cat }}\left(\mathrm{s}^{-1}\right)$ & $K_{\mathrm{M}}\left(\mathrm{mg} \cdot \mathrm{ml}^{-1}\right)$ & $k_{\mathrm{cat}} / K_{\mathrm{M}}\left(\mathrm{ml} \cdot \mathrm{mg}^{-1} \cdot \mathrm{s}^{-1}\right)$ \\
\hline AnMan5A & 90 & 1.4 & 66.1 \\
AnMan5B & 15 & 2.6 & 5.9 \\
AnMan5C & 220 & 3.1 & 70.7 \\
TrMan5A & 240 & 0.6 & 400 \\
\hline
\end{tabular}

${ }^{\mathrm{a}}$ Data from (Rosengren et al. 2012) 
End product formation from mannan

and manno-oligosaccharides

When incubated over night with linear ivory nut mannan and manno-oligosaccharides $\mathrm{M}_{3}-\mathrm{M}_{6}$ AnMan5B generated $\mathrm{M}_{2}$ as end product in contrast to AnMan5A, AnMan5C and TrMan5A as analysed with TLC (data not shown). Under similar conditions, AnMan5A and TrMan5A produced $\mathrm{M}_{2}$ and $\mathrm{M}_{3}$ while AnMan5C produced $\mathrm{M}_{1}$ and $\mathrm{M}_{2}$. Similar to the other $\beta$-mannanases, mannobiose was not hydrolysed by AnMan5B.

Product formation from incubations with $\mathrm{M}_{4}$

A time course analysis of the product formation from $5 \mathrm{mM}$ $\mathrm{M}_{4}$, analysed with TLC (Supplemental Fig. S2), showed that AnMan5B again stood out compared to AnMan5A, AnMan5C and TrMan5A. Similar to the other enzymes, AnMan5B produced $\mathrm{M}_{3}$ and $\mathrm{M}_{2}$ from $\mathrm{M}_{4}$, but in addition AnMan5B also appeared to generate transglycosylation products to a strikingly higher extent (Supplemental Fig. S2, lane B1). TrMan5A was previously shown to perform transglycosylation with $\mathrm{M}_{4}$ (Harjunpaa et al. 1999; Rosengren et al. 2012). AnMan5A and AnMan5C were also reported to generate transglycosylation products when incubated with high concentration $(30 \mathrm{mM})$ of $\mathrm{M}_{4}$ (Dilokpimol et al. 2011). To further investigate and compare the transglycosylation capacity, AnMan5B and TrMan5A were incubated at similar conditions to those used previously with AnMan5A and AnMan5C (Dilokpimol et al. 2011). Using HPAEC-PAD analysis, transglycosylation products $\mathrm{M}_{5}$ and $\mathrm{M}_{6}$ were detected for both AnMan5B and TrMan5A, and in addition $\mathrm{a}_{7}$ peak was seen in the chromatogram for AnMan5B (Fig. 2a). However, using MALDI-TOF MS analysis, products up to DP14 for AnMan5B (Fig. 2b) and DP9 for TrMan5A (Fig. 2c) were detected.

Quantification with HPAEC-PAD of the products generated in the $3 \mathrm{~h}$ time course reaction, showed that AnMan5B (Fig. 3a) generated higher amounts of transglycosylation products $\mathrm{M}_{5}-\mathrm{M}_{7}$ compared to TrMan5A (Fig. 3b). AnMan5B and TrMan5A differed not only in the amount of transglycosylation products generated at comparable substrate conversions between 40 and $80 \%$, but also in the product profile. AnMan5B continuously generated more of the transglycosylation products $\mathrm{M}_{5}-\mathrm{M}_{7}$ (Fig. 3a) while keeping the amount of $\mathrm{M}_{2}$ and $\mathrm{M}_{3}$ products rather constant (Fig. 3c). With TrMan5A, the transglycosylation products decreased after a certain time (60 min) of incubation (Fig. 3b) and the amount of $\mathrm{M}_{1}-\mathrm{M}_{3}$ increased (Fig. 3d).

Overall, AnMan5B differed in product formation compared to TrMan5A, and also compared to AnMan5A and AnMan5C (Dilokpimol et al. 2011), when incubated with a high concentration of $\mathrm{M}_{4}(30 \mathrm{mM})$. AnMan5B gave a higher total yield of transglycosylation products $\mathrm{M}_{5}-\mathrm{M}_{7}$ compared to the other three enzymes. AnMan5C generated more $\mathrm{M}_{5}$ and $\mathrm{M}_{6}$ than both AnMan5A and TrMan5A. In comparison, AnMan5B generated similar amounts of $\mathrm{M}_{6}$ as AnMan5C, but higher amounts of $\mathrm{M}_{5}$ and also substantial amounts of $\mathrm{M}_{7}$, not seen for AnMan5C (Dilokpimol et al. 2011). These results together with the detection of products up to DP14 in the MALDI-TOF MS analysis (Fig. 2b) and the absence of mannose production while $\mathrm{M}_{3}$ is produced (Figs. 2a and 3c) indicate an exceptionally efficient glycosyl transfer capacity by AnMan5B.

Kinetics with manno-oligosaccharides

To get further insight in interactions and catalytic efficiency with shorter substrates, $k_{\text {cat }} / K_{\mathrm{M}}$ on manno-oligosaccharides was determined for AnMan5B. A low substrate concentration $(50 \mu \mathrm{M})$ was used, to limit transglycosylation. The threshold in catalytic efficiency was between $\mathrm{M}_{3}$ and $\mathrm{M}_{4}$. AnMan5B had a higher $k_{\text {cat }} / K_{\mathrm{M}}$ on $\mathrm{M}_{4}$ compared to AnMan5A, AnMan5C and TrMan5A (Table 3). The similar $k_{\text {cat }} / K_{\mathrm{M}}$ on $\mathrm{M}_{4}$ and $\mathrm{M}_{5}$ for AnMan5B indicated that occupation of substrate at additional subsites above four did not considerably enhance the catalytic efficiency, although a slight increase was seen with $\mathrm{M}_{6}$. Thus, this suggests that occupation of at least four subsites is required for efficient catalysis. This distinguishes AnMan5B from what was reported for AnMan5A, AnMan5C and TrMan5A, where $k_{\text {cat }} / K_{\mathrm{M}}$ constantly increased with increasing DP of the manno-oligosaccharides up to the tested $\mathrm{M}_{6}$ (Table 3).

Incubations with manno-oligosaccharides in $\mathrm{H}_{2}{ }^{18} \mathrm{O}$

Some information on preferred substrate binding was previously reported for AnMan5A, AnMan5C (Dilokpimol et al. 2011) and TrMan5A (Rosengren et al. 2012). To get more detailed information on how manno-oligosaccharides bind to the active site of AnMan5B, incubations were set up in ${ }^{18} \mathrm{O}$ labelled water as described by (Couturier et al. 2013; Hekmat et al. 2010; Rosengren et al. 2012) to analyse the cleavage pattern. Non-enzymatic incorporation of ${ }^{18} \mathrm{O}$ was prevented by setting up the incubations at low temperature $\left(8^{\circ} \mathrm{C}\right)$, in accordance with our previous study (Hekmat et al. 2010). Interestingly, at the same conditions as used with AnMan5A and AnMan5C (data not shown) and previously with other $\beta$ mannanases (Couturier et al. 2013; Hekmat et al. 2010; Rosengren et al. 2012), no ${ }^{18} \mathrm{O}$-labelled products could be detected with AnMan5B in initial stages (up to $1 \mathrm{~h}$ ) of substrate conversion. In addition, transglycosylation products up to DP9 from $\mathrm{M}_{4}$ and DP12 from $\mathrm{M}_{5}$ and $\mathrm{M}_{6}$ were detected in the MALDI-TOF MS spectra (Supplemental Fig. S3a, b and c respectively), which was not seen with any of the other 

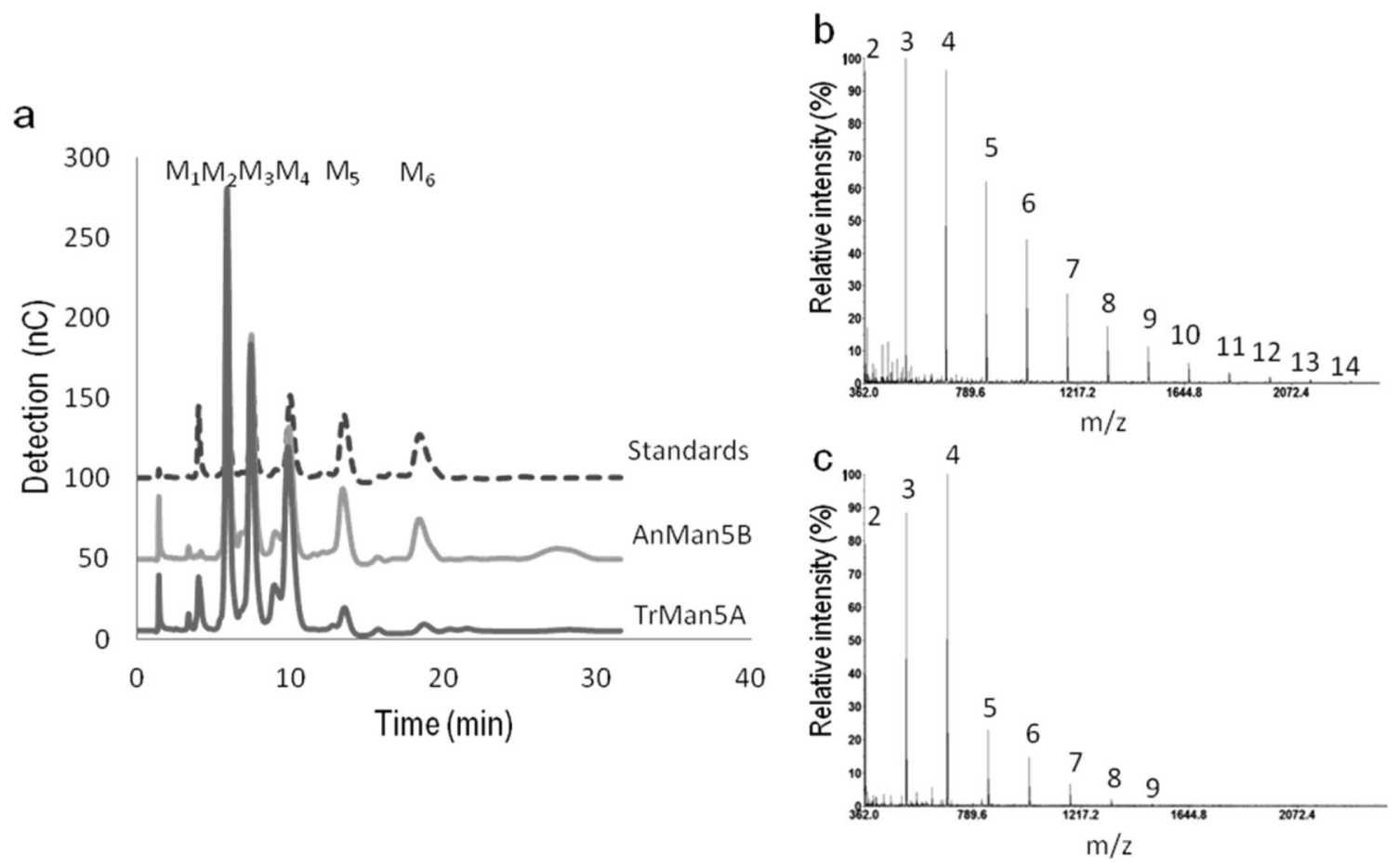

Fig. 2 a HPAEC-PAD chromatogram of the $30 \mathrm{mM} \mathrm{M}_{4}$ incubation with AnMan5B and TrMan5A for $3 \mathrm{~h}$. Manno-oligosaccharide standards are included and marked $\mathrm{M}_{1}-\mathrm{M}_{6}$. b MALDI-TOF MS analysis of the $3 \mathrm{~h}$ reaction with AnMan5B and $\mathrm{M}_{4}$, showing peaks of manno-

oligosaccharides of DP2-DP14. c MALDI-TOF MS analysis of the $3 \mathrm{~h}$ reaction with $\operatorname{TrMan} 5 \mathrm{~A}$ and $\mathrm{M}_{4}$ showing peaks of manno-oligosaccharides of DP2-DP9

a

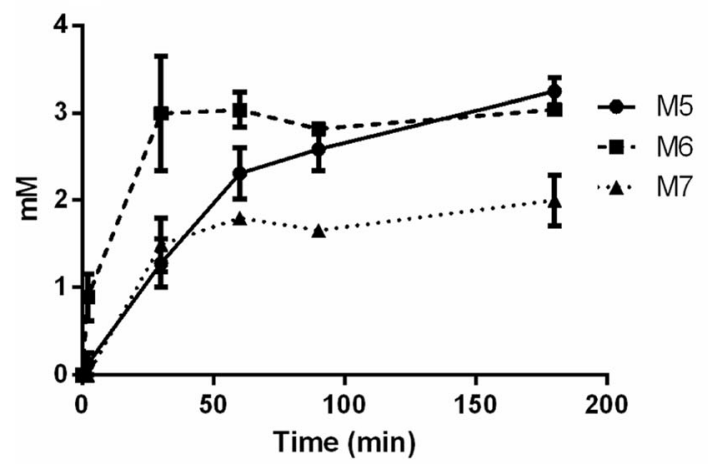

C

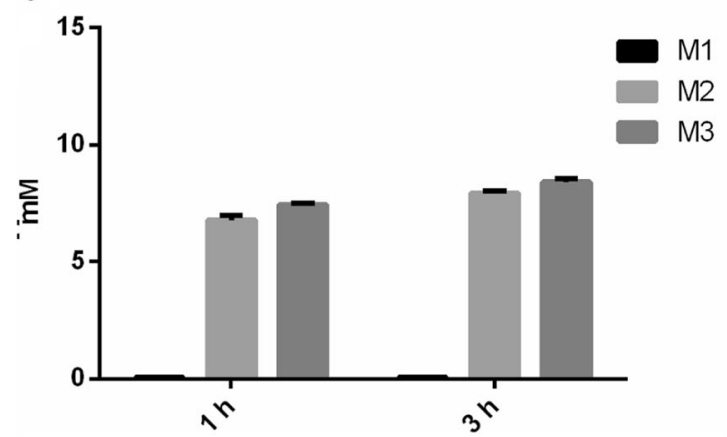

Fig. 3 Products generated in reactions with $30 \mathrm{mM} \mathrm{M}_{4}$ using AnMan5B or TrMan5A, quantified with HPAEC-PAD. a Transglycosylation products $\mathrm{M}_{5}-\mathrm{M}_{7}$ generated with AnMan5B, b Transglycosylation products b

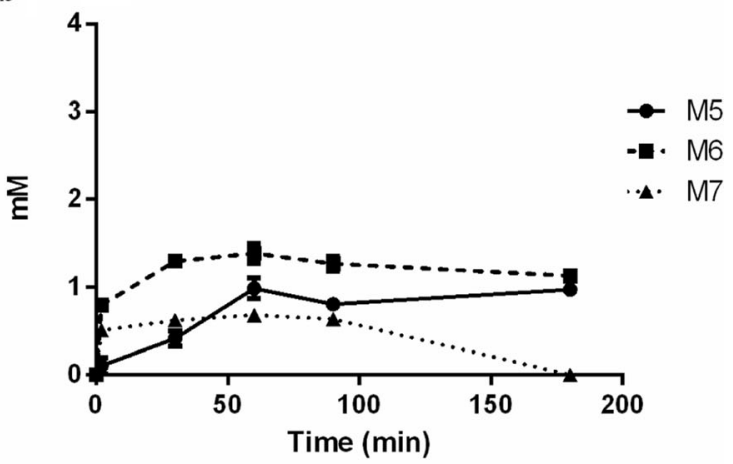

d

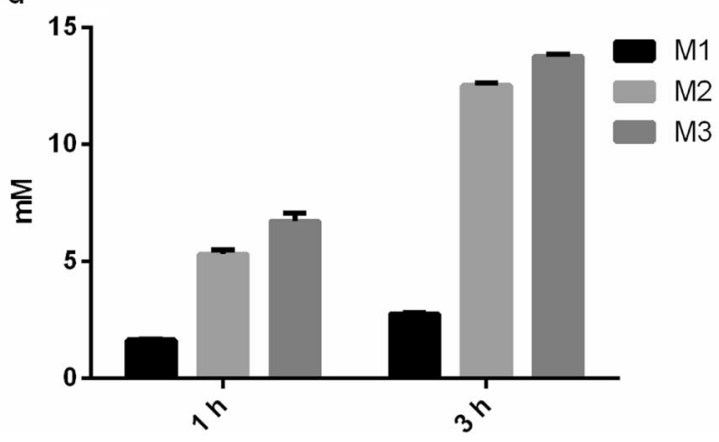

$\mathrm{M}_{5}-\mathrm{M}_{7}$ generated with TrMan5A, c Products $\mathrm{M}_{1}-\mathrm{M}_{3}$ generated with AnMan5B after 1 and $3 \mathrm{~h}, \mathbf{d}$ Products $\mathrm{M}_{1}-\mathrm{M}_{3}$ generated with TrMan5A after 1 and 3 h. Error bars show deviation in double analysis 
Table 3 Kinetic efficiency on manno-oligosaccharides for AnMan5B and comparison to data reported for AnMan5A, AnMan5C and TrMan5A

\begin{tabular}{|c|c|c|c|c|}
\hline \multirow[t]{2}{*}{ Substrate } & \multicolumn{4}{|c|}{$k_{\text {cat }} / K_{\mathrm{M}}\left(\mathrm{s}^{-1} \mathrm{mM}^{-1}\right)$} \\
\hline & AnMan5B & AnMan5 $A^{a}$ & AnMan5C $C^{a}$ & $\operatorname{TrMan} 5 \mathrm{~A}^{\mathrm{b}}$ \\
\hline $\mathrm{M}_{3}$ & $0.16 \pm 0.02$ & Not reported & Not reported & Not reported \\
\hline $\mathrm{M}_{4}$ & $40 \pm 4.3$ & 6 & 7 & 19.4 \\
\hline $\mathrm{M}_{5}$ & $36.6 \pm 2.6$ & 23 & 61 & 163 \\
\hline $\mathrm{M}_{6}$ & $61.6 \pm 6.7$ & 109 & 215 & 400 \\
\hline
\end{tabular}

${ }^{a}$ Data from Dilokpimol et al. (2011)

${ }^{\mathrm{b}}$ Data from Rosengren et al. (2012)

enzymes tested using this relatively low substrate concentration $(0.8 \mathrm{mM})$.

No ${ }^{18} \mathrm{O}$-labelled product could be seen with AnMan5B until the reaction was allowed to proceed substantially further (up to $24 \mathrm{~h}$ incubation), which resulted in detection of small peaks of ${ }^{18} \mathrm{O}$-labelled $\mathrm{M}_{2}$ and $\mathrm{M}_{3}$ in the MALDI-TOF MS spectra (data not shown). The absence of ${ }^{18} \mathrm{O}$-labelled products, together with the substantial amount of transglycosylation products detected in the same reactions, strongly indicates that saccharides rather than water acted as main acceptor for AnMan5B. Thus, AnMan5B has exceptionally efficient glycosyl transfer capacity also at relatively low substrate concentrations $(0.8 \mathrm{mM})$. The non-labelled $\left({ }^{16} \mathrm{O}\right)$ products with lower DP than the original substrate (for example $\mathrm{M}_{2}$ and $\mathrm{M}_{3}$ from $\mathrm{M}_{4}$ ) are then produced in the initial aglycone release, at the first step of the reaction where the covalent intermediate between enzyme and substrate is formed.

\section{Transfer to alcohol acceptors}

The interesting finding that AnMan5B seemed to prefer saccharides as acceptor molecules instead of water, at tested substrate concentrations $\geq 0.8 \mathrm{mM}$, lead us to analyse whether alcohols could be used as acceptors. Transfer to methanol (Fig. 4) and butanol (data not shown) was tested with AnMan5B and compared to AnMan5A and AnMan5C, using $5 \mathrm{mM} \mathrm{M}_{4}$ as donor substrate, in a similar way to what was done previously with TrMan5A (Rosengren et al. 2012). MALDI-TOF MS analysis showed that AnMan5A gave alcohol conjugates with $\mathrm{M}_{2}$ and $\mathrm{M}_{3}$ (Fig. 4a), similarly to TrMan5A (Rosengren et al. 2012). AnMan5C generated alcohol conjugates with $\mathrm{M}_{2}$ to a higher extent (deduced from the relative peak intensities) compared to the other enzymes, and gave only little amount of $\mathrm{M}_{3}$-conjugate (Fig. 4c). However, when AnMan5B was incubated under similar conditions to AnMan5A and AnMan5C, no detectable alcohol conjugates were generated and only negligible amounts were detected even after prolonged incubation time ( $>5 \mathrm{~h}$, data not shown). On the other hand, substantial amounts of transglycosylation products up to DP14 were detected in the spectra for
AnMan5B (Fig. 4b) but not for AnMan5A (Fig. 4a) or AnMan5C (Fig. 4c).

Transfer to $\mathrm{G}_{2} \mathrm{M}_{5}$ by AnMan5B

The results from the alcohol transfer reactions indicated that AnMan5B was less efficient in transferring to alcohol acceptors compared to AnMan5A, AnMan5C and TrMan5A, while the transfer to manno-oligosaccharides was considerably more efficient. Mannopentaose substituted with galactose at positions two and three, $\mathrm{G}_{2} \mathrm{M}_{5}$, was not hydrolysed by AnMan5B (data not shown). Interestingly, MALDI-TOF MS analysis showed that AnMan5B seemed to be able to use $\mathrm{G}_{2} \mathrm{M}_{5}$ as acceptor, using $\mathrm{M}_{4}$ as donor substrate, generating conjugates from DP8 to DP12 (Fig. 5a). To distinguish transfer products from linear manno-oligosaccharides with the same DP and therefore the same molecular weight, incubations where $\mathrm{G}_{2} \mathrm{M}_{5}$ had been pre-labelled with ${ }^{18} \mathrm{O}$ were set up. The detection of DP8-DP11 products with additional masses of $2 \mathrm{Da}$ (resulting from the ${ }^{18} \mathrm{O}$ instead of ${ }^{16} \mathrm{O}$ on the $\mathrm{G}_{2} \mathrm{M}_{5}$ ) confirmed that AnMan5B indeed used $\mathrm{G}_{2} \mathrm{M}_{5}$ as acceptor (Fig. 5b).

\section{Homology modelling}

As an initial step towards finding structural features that are responsible for the functional properties of AnMan5B, a homology model was generated using the crystal structure of the catalytic domain of $\beta$-mannanase TrMan5A as template (PDB entry 1QNR (Sabini et al. 2000), $48 \%$ sequence identity to AnMan5B). Compared to the template the AnMan5B model showed an overall well-conserved catalytic site with no apparent differences in subsites -2 and -1 (data not shown). One notable difference could be seen at a non-conserved position on the aglycone side (Fig. 6), where AnMan5B has Trp242 instead of Leu207 in the template. Trp242 could potentially contribute to sugar monomer binding in subsite +2 .

\section{Discussion}

Fundamental studies of $\beta$-mannanases and other enzymes which are active on plant cell wall carbohydrates not only increases our knowledge about natural biomass conversion, but also provides important information that can guide in the selection of enzymes for certain applications. Sequence analysis and classification of $\beta$-mannanases into families and subfamilies provide useful information, but cannot alone predict the fine-tuned specificity of individual enzymes. The functional diversity needs to be further investigated by detailed biochemical characterisation, as exemplified in the present study where paralogous and homologous $\beta$-mannanases belonging to the same family, and even the same subfamily (GH5_7), 


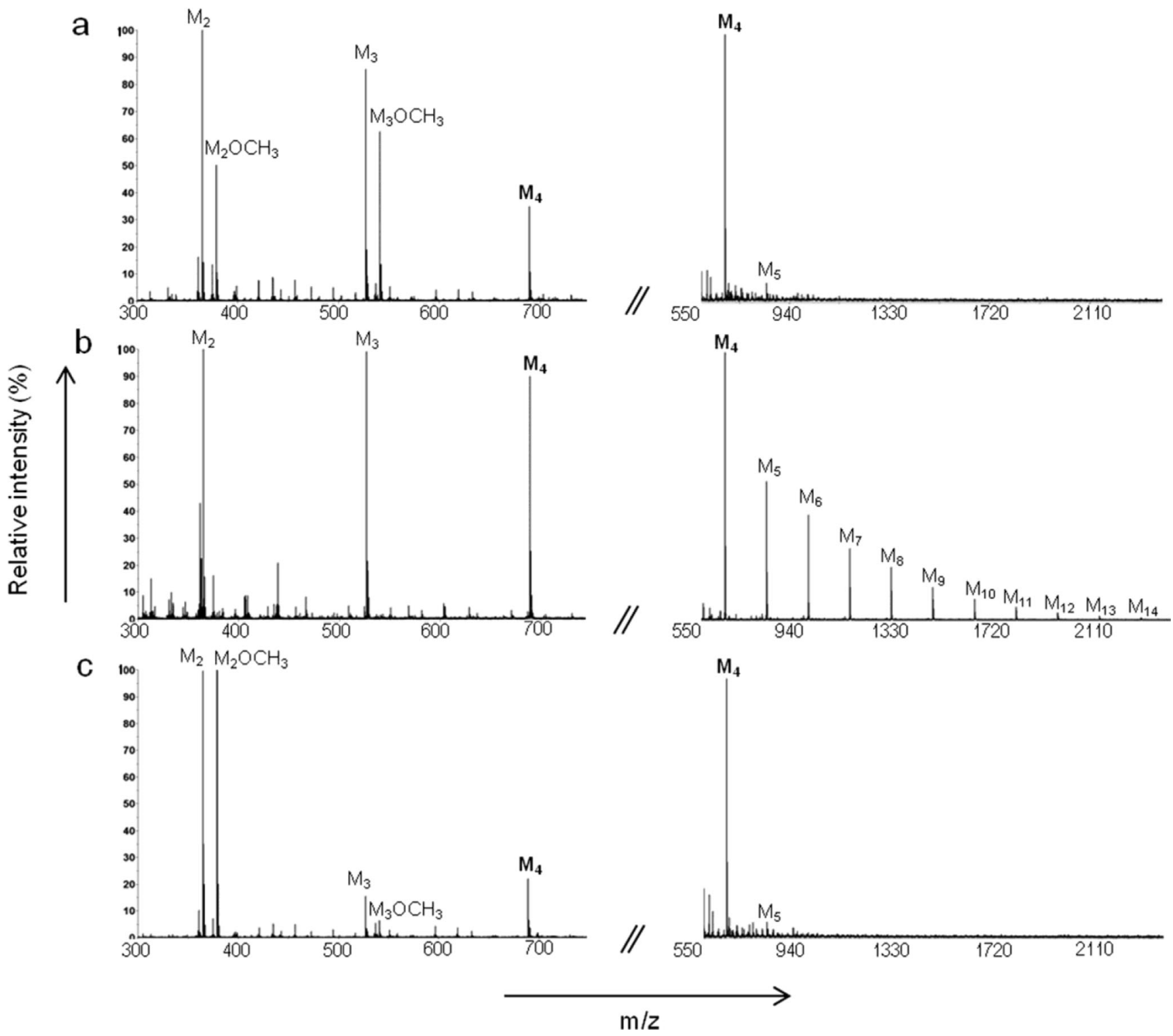

Fig. 4 MALDI-TOF MS analysis of reactions with $\mathrm{M}_{4}$ and $\mathrm{MeOH}$. The spectra show samples incubated at the same conditions for $1,5 \mathrm{~h}$ with a AnMan5A, b AnMan5B and $\mathbf{c}$ AnMan5C

were shown to have quite different functional properties. In terms of hydrolase/transglycosylase activity, plant enzymes acting on xyloglucan are among the most well studied (Eklof and Brumer 2010; Eklof et al. 2013; Kaewthai et al. 2013) and only a few plant $\beta$-mannanases have been studied (Schroder et al. 2006; Wang et al. 2014). In this study, we focus on differences in transglycosylation capacity among fungal A. nidulans $\beta$-mannanases and related enzymes of GH5 7 . Transglycosylation is of interest, e.g. in enzyme catalysed synthesis, but could potentially be counterproductive for efficient mannan degradation. Differences were seen in hydrolytic efficiency on LBG, product profiles, transglycosylation capacity with manno-oligosaccharides, and in acceptor usage.

A $\beta$-mannanase such as AnMan5B, with low $k_{\mathrm{cat}} / K_{\mathrm{M}}$ on galactomannan (Table 2) may be specialized to have other functions than hydrolysing polymeric substrates. The low hydrolytic efficiency on LBG, together with the absence of ${ }^{18} \mathrm{O}$-labelled products when incubated with mannooligosaccharides in $\mathrm{H}_{2}{ }^{18} \mathrm{O}$ (Supplemental Fig. S3), strongly suggests that AnMan5B prefers to use sugars as acceptors instead of water. The yield of transglycosylation products from mannotetraose (Fig. 3a) and the MALDI-TOF MS detection of products up to DP14 (Fig. 2b) showed that AnMan5B indeed has an exceptionally good capacity to generate transglycosylation products. The amount of $\mathrm{M}_{2}$ and $\mathrm{M}_{3}$ remained rather constant during the time course studied (Fig. 3c) and no mannose was detected although $\mathrm{M}_{3}$ was produced (Fig. 2a). This further indicates that the main catalytic event for AnMan5B is transglycosylation. 
Fig. 5 MALDI-TOF MS spectra showing the transfer to $\mathrm{G}_{2} \mathrm{M}_{5}$ by AnMan5B using $\mathrm{M}_{4}$ as donor substrate. a Spectra from the incubation with $5 \mathrm{mM} \mathrm{M}_{4}$ and $5 \mathrm{mM} \mathrm{G}_{2} \mathrm{M}_{5}$, giving transfer products of DP8-DP12. b Spectra from the incubation with $0.8 \mathrm{mM} \mathrm{M}_{4}$ and $0.8 \mathrm{mM}$ $\mathrm{G}_{2} \mathrm{M}_{5^{-}}{ }^{18} \mathrm{O}$ giving transfer products of DP8-DP11 with additional mass of $2 \mathrm{Da}$, confirming that there is transfer to the ${ }^{18} \mathrm{O}$-labelled $\mathrm{G}_{2} \mathrm{M}_{5}$. The

${ }^{18} \mathrm{O}$-labelled $\mathrm{M}_{6}$ is a contaminant in the $\mathrm{G}_{2} \mathrm{M}_{5^{-}}{ }^{18} \mathrm{O}$ preparation

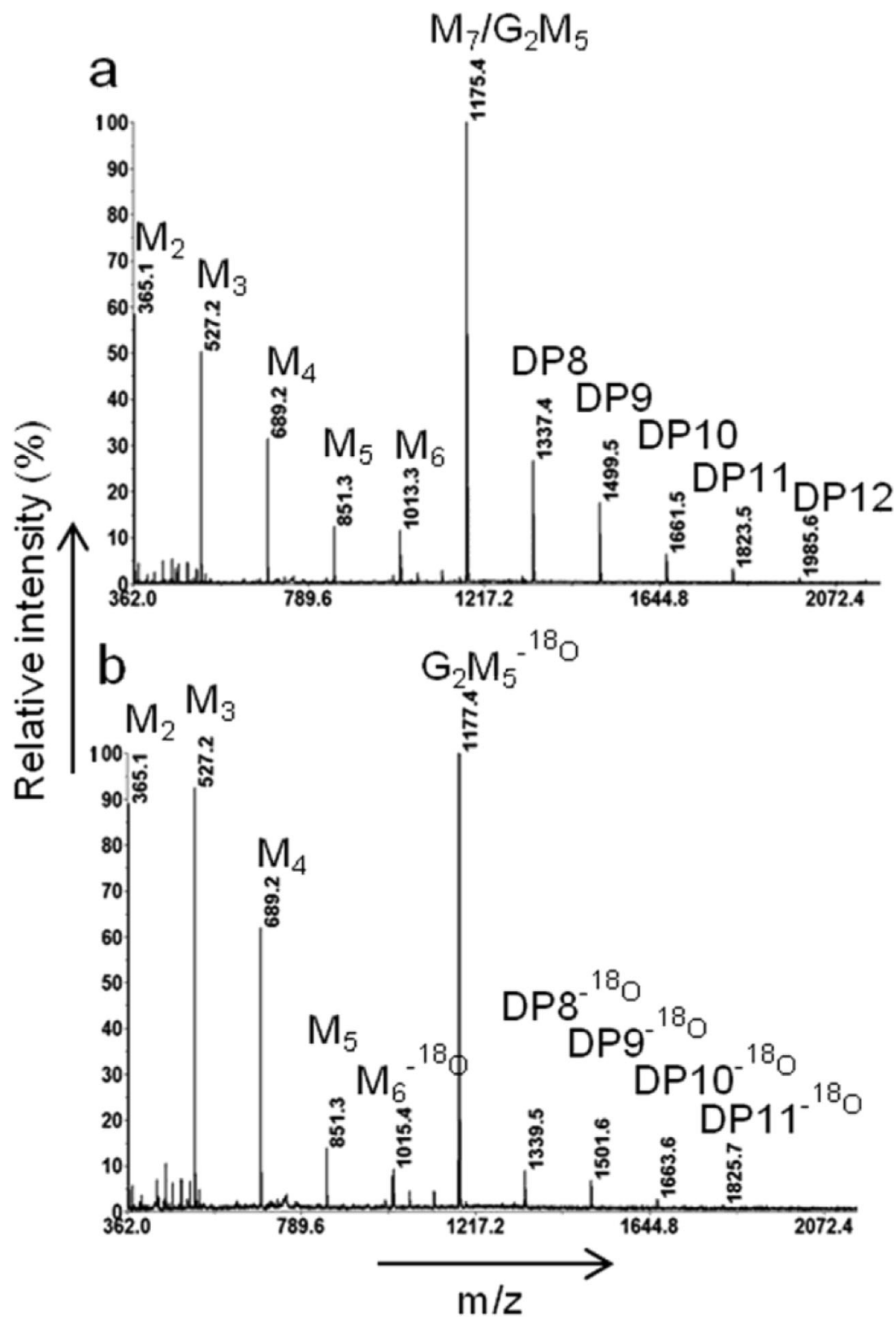

Increasing the substrate concentration increases the possibility of formation of transglycosylation products (Dias et al. 2004; Sinnott 1990). Interestingly, with AnMan5B, transglycosylation products were generated even at relatively low substrate concentrations (Supplemental Fig. S3), highlighting its potential in sugar synthesis applications. A great advantage of native transglycosylation as seen with AnMan5B is that natural sugars can be used in the synthesis, compared to the glycosynthase approach where fluorinated substrates are required (Hancock et al. 2006). Furthermore, the capability of AnMan5B to transfer to $\mathrm{G}_{2} \mathrm{M}_{5}$ (Fig. 5) demonstrates the synthesis of substituted complex products of defined size, which is otherwise difficult to achieve.
AnMan5B showed a significantly lower capacity to transfer to alcohol acceptors compared to AnMan5A and AnMan5C (Fig. 4). In the case of methanol, this is potentially connected to the preference for using sugars as acceptors instead of water, as lower alcohols could be regarded as water analogues. Exclusion of water has previously been reported as one factor responsible for high sugar synthesis capacity by a GH31 glycosidase (Larsbrink et al. 2012). AnMan5A and AnMan5C were both reported to perform transglycosylation reactions with mannotetraose (Dilokpimol et al. 2011), but to a lower extent than AnMan5B. In addition, they were both more efficient in LBG hydrolysis and both AnMan5A and AnMan5C generated hydrolysis products with manno- 


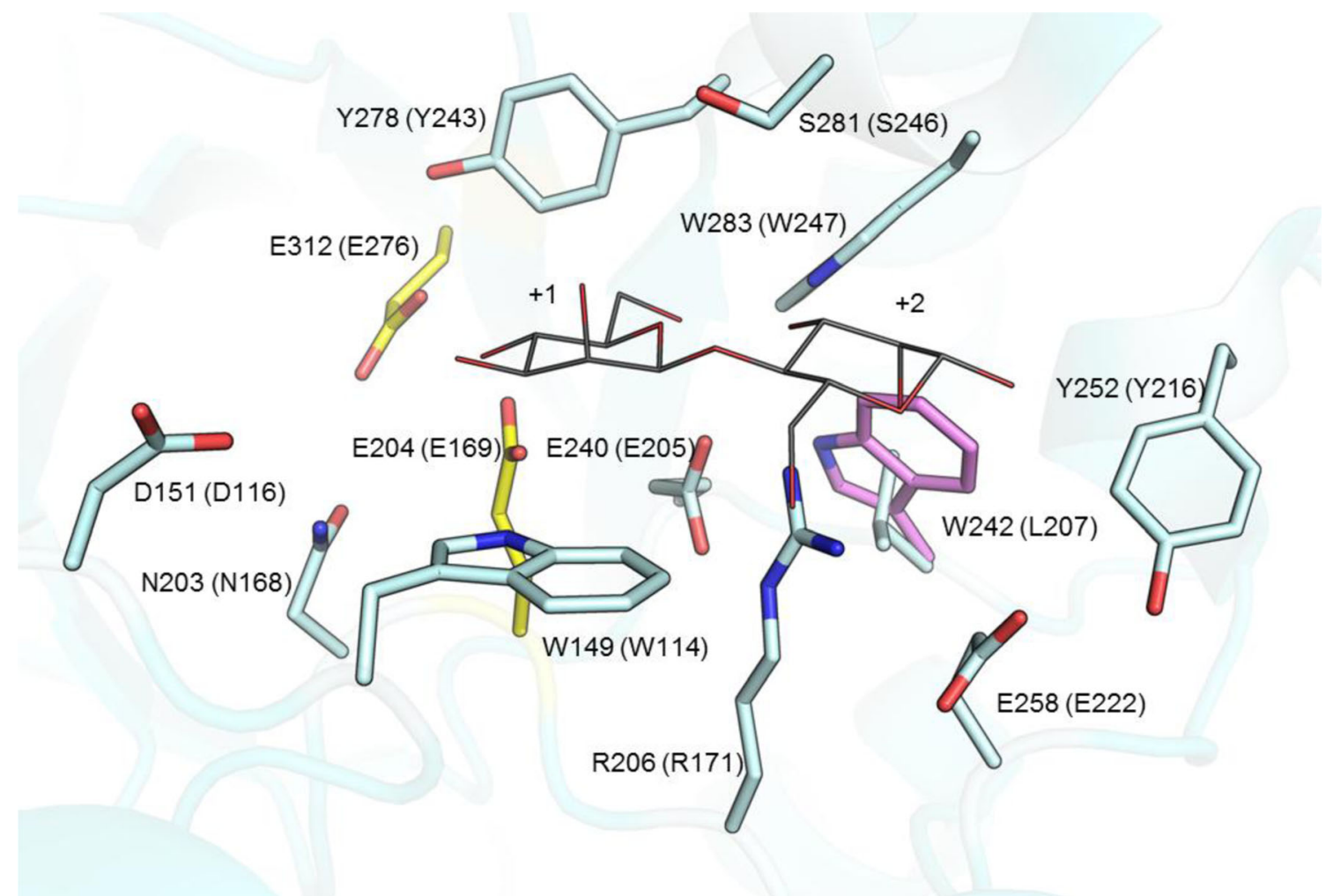

Fig. 6 Close up on the active site showing an overlay of the structure of TrMan5A (cyan) in complex with mannobiose ( grey) at subsite +1 and +2 and the homology model of AnMan5B (violet). Oxygens are in red, nitrogens are in blue and the catalytic residues are shown in yellow. The amino acids are numbered according to the sequence of AnMan5B with

oligosaccharides when incubated in $\mathrm{H}_{2}{ }^{18} \mathrm{O}$, similar to TrMan5A (Rosengren et al. 2012). In the reactions with alcohols, AnMan5A and AnMan5C both produced conjugates with methanol and butanol, which was not seen with AnMan5B. The product distribution of alcohol conjugates differed, reflecting the preferred binding of mannotetraose. AnMan5C generated almost exclusively alcohol conjugate with $\mathrm{M}_{2}$ while AnMan5A generated conjugates also with $\mathrm{M}_{3}$ (Fig. 4). TrMan5A was also reported to produce $\mathrm{M}_{2}$ - and $\mathrm{M}_{3}$-conjugates with methanol and butanol (Rosengren et al. 2012). Interestingly, a subsite +2 mutant of TrMan5A with impaired transglycosylation capacity to sugars was able to transfer to alcohols, indicating that transglycosylation capability onto sugar acceptors is not necessarily a criterion for alcohol transfer capability.

Kinetic analysis with manno-oligosaccharides showed that AnMan5B requires occupation of at least four subsites for efficient substrate conversion (Table 3). From the incubations in $\mathrm{H}_{2}{ }^{18} \mathrm{O}$, although no ${ }^{18} \mathrm{O}$-labelled products were generated, the product profile could reveal the preferred binding of substrate. AnMan5B prefers to bind substrate so that it occupies at least subsite -2 and +2 . The initial product formation from $\mathrm{M}_{4}$ was $\mathrm{M}_{2}$ and $\mathrm{M}_{6}$, where non-labelled $\mathrm{M}_{2}$ was produced in the aglycone release step and $\mathrm{M}_{6}$ was produced by corresponding number in the 1QNR template in parenthesis. Residues within $6 \AA$ of the mannobiose are conserved between the model and the template, except for W242 in the AnMan5B, which corresponds to L207 in TrMan5A

transglycosylation onto another $\mathrm{M}_{4}$ acceptor molecule. When reacting with $\mathrm{M}_{5}$, the first aglycone product released was nonlabelled $\mathrm{M}_{3}$ and the transglycosylation product was $\mathrm{M}_{7}$, indicating binding from subsite -2 to +3 . The same pattern was seen in the transfer reactions with $\mathrm{G}_{2} \mathrm{M}_{5}$, where the initial products were $\mathrm{M}_{2}$ and $\mathrm{G}_{2} \mathrm{M}_{7}$ (data not shown).

Structural data can provide insight in molecular details that are connected to certain functions. Of the six crystal structures of eukaryotic GH5 $\beta$-mannanases present to date (Bourgault et al. 2005; Couturier et al. 2013; Goncalves et al. 2012; Larsson et al. 2006; Mizutani et al. 2012; Sabini et al. 2000), transglycosylation has been reported for four of the enzymes. Three are in GH5 7 (Couturier et al. 2013; Sabini et al. 2000; Schroder et al. 2006) and one is in GH5 10 (Larsson et al. 2006). The three $\beta$-mannanase $3 \mathrm{D}$ structures from subfamily GH5 7 all have an arginine in the +2 subsite and the one in subfamily GH5 10 has two tryptophans in the +2 subsite. The arginine that provides mannosyl affinity in +2 in $\operatorname{TrMan} 5 \mathrm{~A}$, shown to be important for transglycosylation capacity (Rosengren et al. 2012), is also present in AnMan5A, AnMan5B and AnMan5C. In addition, it has previously been shown that a non-conserved tryptophan located in subsite +1 of AnMan5C was responsible for the higher yield of transglycosylation products generated with AnMan5C 
compared to AnMan5A (Dilokpimol et al. 2011). The importance of subsites in the aglycone region for efficient transglycolsylation has also been shown for GH18 chitinases and a GH10 xylanase (Armand et al. 2001; Zakariassen et al. 2011).

An initial step in the direction of pinpointing structural features that are connected to specific functions was taken with AnMan5B by creating a homology model. The model showed an overall well-conserved catalytic site compared to the template structure TrMan5A, with the only notable difference seen on the aglycone side where AnMan5B had a tryptophan (Trp242) instead of a leucine in the template (Fig. 6). Tryptophan is known to be involved in stacking interactions with sugar in the active site of carbohydrate active enzymes (Eide et al. 2013; Larsson et al. 2006). Most likely, there is a combination of factors in the structure of AnMan5B that contribute to high transglycosylation capacity, where R206, analogous to R171 in TrMan5A, might play one of the roles in providing affinity in the aglycone subsites, potentially together with W242.

This study highlights the importance of the selection of a suitable $\beta$-mannanase depending on the application. We have provided insight in features that play a role in different functions of $\beta$-mannanases. In this respect, AnMan5B is clearly different from its paralogs AnMan5A and AnMan5C and the homolog TrMan5A. All these enzymes, and several other $\beta$-mannanases of GH5, can transglycosylate. This is useful for enzyme catalysed synthesis. However, from lower mannooligosacharides AnMan5B is producing the longest transglycosylation products so far detected (DP14). AnMan5B has also a significantly lower $k_{\text {cat }}$ and $k_{\text {cat }} / K_{\mathrm{M}}$ using polymeric mannan (LBG) as a substrate in an assay detecting hydrolytic activity. Furthermore, the absence of ${ }^{18} \mathrm{O}$-labelled products from manno-oligosaccharide incubations in $\mathrm{H}_{2}{ }^{18} \mathrm{O}$ and the build-up of significant amounts of long transglycosylation products suggest that AnMan5B is prone to use saccharide acceptors rather than water. This view is further underlined by AnMan5B not being able to use methanol as acceptor, given the structural similarity to water. A contributing factor to these observations may be high affinity for saccharide acceptors binding in the aglycone region of AnMan5B as indicated by the presence of Trp242 potentially contributing to sugar binding in the +2 subsite, in addition to Arg206 which is semi-conserved in GH5 and shown to be important for transglycosylation (Rosengren et al. 2012).

Acknowledgments This study was funded by the Swedish agency for Innovation Systems (Vinnova) through projects P37549-1 and 201303024 and the Antidiabetic Food Center. Also the Swedish Research Council for Environment, Agricultural Sciences and Spatial Planning (FORMAS) is acknowledged for funding through grant 213-2011-1620. K. K. was supported by the Sven and Lilly Lawski foundation.

Conflict of interest The authors declare that they have no conflict of interest.
Open Access This article is distributed under the terms of the Creative Commons Attribution License which permits any use, distribution, and reproduction in any medium, provided the original author(s) and the source are credited.

\section{References}

Armand S, Andrews SR, Charnock SJ, Gilbert HJ (2001) Influence of the aglycone region of the substrate binding cleft of Pseudomonas xylanase 10A on catalysis. Biochemistry 40(25):7404-7409

Aspeborg H, Coutinho PM, Wang Y, Brumer H 3rd, Henrissat B (2012) Evolution, substrate specificity and subfamily classification of glycoside hydrolase family 5 (GH5). BMC Evol Biol 12:186

Bauer S, Vasu P, Mort AJ, Somerville CR (2005) Cloning, expression, and characterization of an oligoxyloglucan reducing end-specific xyloglucanobiohydrolase from Aspergillus nidulans. Carbohydr Res 340(17):2590-2597

Bauer S, Vasu P, Persson S, Mort AJ, Somerville CR (2006) Development and application of a suite of polysaccharide-degrading enzymes for analyzing plant cell walls. Proc Natl Acad Sci U S A 103(30): 11417-11422

Bien-Cuong D, Thi-Thu D, Berrin JG, Haltrich D, Kim-Ahn T, Sigoillot JC, Yamabhai M (2009) Cloning, expression in Pichia pastoris, and characterization of a thermostable GH5 mannan endo-1,4-beta-mannosidase from Aspergillus niger BK01. Microb Cell Factories 8:59

Bounias M (1980) N-(1-naphthyl) ethylenediamine dihydrochloride as a new reagent for nanomole quantification of sugars on thin-layer plates by a mathematical calibration process. Anal Biochem 106(2):291-295

Bourgault R, Oakley AJ, Bewley JD, Wilce MCJ (2005) Threedimensional structure of $(1,4)$-beta-D-mannan mannanohydrolase from tomato fruit. Protein Sci 14(5):1233-1241

Cantarel BL, Coutinho PM, Rancurel C, Bernard T, Lombard V, Henrissat B (2009) The Carbohydrate-Active EnZymes database (CAZy): an expert resource for Glycogenomics. Nucleic Acids Res 37:233-238

Carvalheiro F, Duarte LC, Girio FM (2008) Hemicellulose biorefineries: a review on biomass pretreatments. J Sci Ind Res 67(11):849-864

Chen VB, Arendall WB, Headd JJ, Keedy DA, Immormino RM, Kapral GJ, Murray LW, Richardson JS, Richardson DC (2010) MolProbity: all-atom structure validation for macromolecular crystallography. Acta Crystallogr D Biol Crystallogr 66:12-21

Coutinho PM, Andersen MR, Kolenova K, vanKuyk PA, Benoit I, Gruben BS, Trejo-Aguilar B, Visser H, van Solingen P, Pakula T, Seiboth B, Battaglia E, Aguilar-Osorio G, de Jong JF, Ohm RA, Aguilar M, Henrissat B, Nielsen J, Stalbrand H, de Vries RP (2009) Post-genomic insights into the plant polysaccharide degradation potential of Aspergillus nidulans and comparison to Aspergillus niger and Aspergillus oryzae. Fungal Genet Biol 46:S161-S169

Couturier M, Roussel A, Rosengren A, Leone P, Stalbrand H, Berrin JG (2013) Structural and biochemical analyses of glycoside hydrolase families 5 and 26 beta-(1,4)-mannanases from Podospora anserina reveal differences upon manno-oligosaccharide catalysis. J Biol Chem 288(20):14624-14635

Davies GJ, Wilson KS, Henrissat B (1997) Nomenclature for sugar-binding subsites in glycosyl hydrolases. Biochem J 321(Pt 2):557-559

Dias FMV, Vincent F, Pell G, Prates JAM, Centeno MSJ, Tailford LE, Ferreira LMA, Fontes C, Davies GJ, Gilbert HJ (2004) Insights into the molecular determinants of substrate specificity in glycoside hydrolase family 5 revealed by the crystal structure and kinetics of Cellvibrio mixtus mannosidase 5A. J Biol Chem 279(24):25517-25526

Dilokpimol A, Nakai H, Gotfredsen CH, Baumann MJ, Nakai N, Abou Hachem M, Svensson B (2011) Recombinant production and 
characterisation of two related GH5 endo-beta-1,4-mannanases from Aspergillus nidulans FGSC A4 showing distinctly different transglycosylation capacity. Biochim Biophys Acta Protein Proteomics 1814(12):1720-1729

Eide KB, Lindbom AR, Eijsink VGH, Norberg AL, Sørlie M (2013) Analysis of productive binding modes in the human chitotriosidase. FEBS Lett 587(21):3508-3513

Eklof JM, Brumer H (2010) The XTH gene family: an update on enzyme structure, function, and phylogeny in xyloglucan remodeling. Plant Physiol 153(2):456-466

Eklof JM, Shojania S, Okon M, McIntosh LP, Brumer H (2013) Structure-function analysis of a broad specificity Populus trichocarpa endo-beta-glucanase reveals an evolutionary link between bacterial licheninases and plant XTH gene products. J Biol Chem 288(22):15786-15799

Emsley P, Cowtan K (2004) Coot: model-building tools for molecular graphics. Acta Crystallogr D Biol Crystallogr 60:2126-2132

Gilbert HJ, Stalbrand H, Brumer H (2008) How the walls come crumbling down: recent structural biochemistry of plant polysaccharide degradation. Curr Opin Plant Biol 11(3):338-348

Goncalves AMD, Silva CS, Madeira TI, Coelho R, de Sanctis D, San Romao MV, Bento I (2012) Endo-beta-D-1,4-mannanase from Chrysonilia sitophila displays a novel loop arrangement for substrate selectivity. Acta Crystallogr D Biol Crystallogr 68:1468-1478

Gridley JJ, Osborn HMI (2000) Recent advances in the construction of beta-D-mannose and beta-D-mannosamine linkages. J Chem Soc Perkin Trans 1(10):1471-1491

Hancock SM, Vaughan DM, Withers SG (2006) Engineering of glycosidases and glycosyltransferases. Curr Opin Chem Biol 10(5):509519

Harjunpaa V, Helin J, Koivula A, Siika-aho M, Drakenberg T (1999) A comparative study of two retaining enzymes of Trichoderma reesei: transglycosylation of oligosaccharides catalysed by the cellobiohydrolase I, Cel7A, and the beta-mannanase, Man5A. FEBS Lett 443(2):149-153

Hekmat O, Lo Leggio L, Rosengren A, Kamarauskaite J, Kolenova K, Stålbrand H (2010) Rational engineering of mannosyl binding in the distal glycone subsites of Cellulomonas fimi endo- $\beta-1,4-$ mannanase: mannosyl binding promoted at subsite -2 and demoted at subsite -3 . Biochemistry 49(23):4884-4896

Hilge M, Gloor SM, Rypniewski W, Sauer O, Heightman TD, Zimmermann W, Winterhalter K, Piontek K (1998) Highresolution native and complex structures of thermostable betamannanase from Thermomonospora fusca - substrate specificity in glycosyl hydrolase family 5. Struct Fold Des 6(11):1433-1444

Iglesias-Fernandez R, Rodriguez-Gacio MC, Barrero-Sicilia C, Carbonero P, Matilla A (2011) Three endo-beta-mannanase genes expressed in the micropylar endosperm and in the radicle influence germination of Arabidopsis thaliana seeds. Planta 233(1):25-36

Kaewthai N, Gendre D, Eklof JM, Ibatullin FM, Ezcurra I, Bhalerao RP, Brumer H (2013) Group III-A XTH genes of Arabidopsis encode predominant xyloglucan endohydrolases that are dispensable for normal growth. Plant Physiol 161(1):440-454

Larsbrink J, Izumi A, Hemsworth GR, Davies GJ, Brumer H (2012) Structural enzymology of Cellvibrio japonicus Agd31B protein reveals alpha-transglucosylase activity in glycoside hydrolase family 31. J Biol Chem 287(52):43288-43299

Larsson AM, Anderson L, Xu BZ, Munoz IG, Uson I, Janson JC, Stalbrand H, Stahlberg J (2006) Three-dimensional crystal structure and enzymic characterization of beta-mannanase Man5A from blue mussel Mytilus edulis. J Mol Biol 357(5):1500-1510

Lawrence AM, Besir HU (2009) Staining of proteins in gels with Coomassie G-250 without organic solvent and acetic acid. J Vis $\operatorname{Exp}(30)$

Lo Leggio L, Larsen S (2002) The 1.62 angstrom structure of Thermoascus aurantiacus endoglucanase: completing the structural picture of subfamilies in glycoside hydrolase family 5. FEBS Lett 523(1-3):103-108

Lombard V, Golaconda Ramulu H, Drula E, Coutinho PM, Henrissat B (2014) The carbohydrate-active enzymes database (CAZy) in 2013. Nucleic Acids Res 42(1):D490-D495

Matsui I, Ishikawa K, Matsui E, Miyairi S, Fukui S, Honda K (1991) Subsite structure of Saccharomycopsis alpha-amylase secreted from Saccharomyces cerevisiae. J Biochem Tokyo 109(4):566-569

Mizutani K, Tsuchiya S, Toyoda M, Nanbu Y, Tominaga K, Yuasa K, Takahashi N, Tsuji A, Mikami B (2012) Structure of beta-1,4mannanase from the common sea hare Aplysia kurodai at 1.05 angstrom resolution. Acta Crystallogr F Struct Biol Cryst Commun 68:1164-1168

Rosengren A, Hagglund P, Anderson L, Pavon-Orozco P, Peterson-Wulff R, Nerinckx W, Stalbrand H (2012) The role of subsite +2 of the Trichoderma reesei beta-mannanase TrMan5A in hydrolysis and transglycosylation. Biocatal Biotransfor 30(3):338-352

Sabini E, Schubert H, Murshudov G, Wilson KS, Siika-Aho M, Penttila M (2000) The three-dimensional structure of a Trichoderma reesei beta-mannanase from glycoside hydrolase family 5. Acta Crystallogr D Biol Crystallogr 56:3-13

Sakon J, Adney WS, Himmel ME, Thomas SR, Karplus PA (1996) Crystal structure of thermostable family 5 endocellulase E1 from Acidothermus cellulolyticus in complex with cellotetraose. Biochemistry 35(33):10648-10660

Schagerlof H, Nilsson C, Gorton L, Tjerneld F, Stalbrand H, Cohen A (2009) Use of O-18 water and ESI-MS detection in subsite characterisation and investigation of the hydrolytic action of an endoglucanase. Anal Bioanal Chem 394(7):1977-1984

Scheller HV, Ulvskov P (2010) Hemicelluloses. In: Merchant S, Briggs WR, Ort D (eds) Annual review of plant biology, Vol 61. Annu Rev Plant Biol, vol 61, pp 263-289

Schroder R, Wegrzyn TF, Sharma NN, Atkinson RG (2006) LeMAN4 endo- $\beta$-mannanase from ripe tomato fruit can act as a mannan transglycosylase or hydrolase. Planta 224(5):1091-1102

Schrödinger LLC (2012) Prime, version 3.1

Schrödinger LLC (2013) The PyMOL molecular graphics system, Version 1.6.0

Sinnott ML (1990) Catalytic mechanisms of enzymatic glycosyl transfer. Chem Rev 90(7):1171-1202

Stalbrand H, Siika-aho M, Tenkanen M, Viikari L (1993) Purification and characterization of two b-mannanases from Trichoderma reesei. J Biotechnol 29:229-242

Tailford LE, Ducros VMA, Flint JE, Roberts SM, Morland C, Zechel DL, Smith N, Bjornvad ME, Borchert TV, Wilson KS, Davies GJ, Gilbert HJ (2009) Understanding how diverse beta-mannanases recognize heterogeneous substrates. Biochemistry 48(29):7009-7018

van Rantwijk F, Oosterom MWV, Sheldon RA (1999) Glycosidasecatalysed synthesis of alkyl glycosides. J Mol Catal B Enzym 6(6):511-532

Wang QP, Tull D, Meinke A, Gilkes NR, Warren RAJ, Aebersold R, Withers SG (1993) Glu280 is the nucleophile in the active site of Clostridium thermocellum CelC, a family-A endo-beta-1,4glucanase. J Biol Chem 268(19):14096-14102

Wang Y, Vilaplana F, Brumer H, Aspeborg H (2014) Enzymatic characterization of a glycoside hydrolase family 5 subfamily 7 (GH5_7) mannanase from Arabidopsis thaliana. Planta 239(3):653-665

Zakariassen H, Hansen MC, Joranli M, Eijsink VGH, Sorlie M (2011) Mutational effects on transglycosylating activity of family 18 chitinases and construction of a hypertransglycosylating mutant. Biochemistry 50(25):5693-5703

Zhang Y, Ju J, Peng H, Gao F, Zhou C, Zeng Y, Xue Y, Li Y, Henrissat B, Gao GF, Ma Y (2008) Biochemical and structural characterization of the intracellular mannanase AaManA of Alicyclobacillus acidocaldarius reveals a novel glycoside hydrolase family belonging to clan GH-A. J Biol Chem 283(46):31551-31558 